\title{
Endogenous Opioids Regulate Long-Term Potentiation of Synaptic Inhibition in the Dentate Gyrus of Rat Hippocampus
}

\author{
C. W. Xie and D. V. Lewis \\ Division of Neurology, Department of Pediatrics, Duke University Medical Center, Durham, North Carolina 27710
}

Long-term potentiation (LTP) of excitatory transmission in the hippocampus has been extensively studied as a synaptic model of learning and memory. Here we report a new form of LTP in which inhibitory synaptic signals are potentiated following tetanic stimulation of an opioid-containing excitatory pathway in the presence of opioid antagonists. The lateral perforant path (LPP) was stimulated at the dentate outer molecular layer of hippocampal slices. Evoked synaptic currents were recorded from dentate granule cells using whole-cell voltage-clamp techniques. A high-frequency stimulus train $(100 \mathrm{~Hz}, 1 \mathrm{sec})$ delivered to the LPP in the presence of naloxone $(1 \mu \mathrm{M})$ was found to induce a long-lasting potentiation ( $20 \mathrm{~min}$ to $2 \mathrm{hr}$ ) in the amplitude of $\gamma$-aminobutyric acid $\left(\mathrm{GABA}_{A}\right)$ receptor-mediated inhibitory postsynaptic currents (IPSCs) of granule cells. Such a potentiation was not observed when tetanizing the LPP in control medium. Naloxone-revealed LTP of LPP-evoked IPSCs did not depend upon the presence of granule cell discharge, and was not accompanied by potentiation of mossy fiber-evoked IPSCs, indicating that feedforward, but not feedback, inhibitory circuits were involved. Induction of this LTP could be completely blocked by the $\mathrm{N}$-methylD-aspartate (NMDA) receptor antagonist D-2-amino-5-phosphonopentanoic acid (D-APV). However, it was not significantly affected by hyperpolarization of granule cells. These results suggest that LTP may occur at the excitatory synapses between LPP terminals and GABAergic interneurons, rather than at the inhibitory synapses between interneurons and granule cells. Further examination using selective opioid antagonists demonstrated that blocking $\delta$, but not $\mu$ and $\kappa$, receptors is critical for inducing LTP of IPSCs in granule cells.

[Key words: opioid, long-term potentiation, dentate gyrus, hippocampus, inhibitory postsynaptic currents (IPSCs), $\delta$ receptors]

LTP is thought to be a synaptic mechanism underlying learning and memory in the brain. Most studies regarding LTP have been focused on the long-term change of excitatory synaptic signals. Recently, a few reports have demonstrated LTP of inhibitory postsynaptic currents (IPSCs) in Mauthner cells of the goldfish

\footnotetext{
Received Sept. 19, 1994; revised Nov. 28, 1994; accepted Dec. 5, 1994

This study was supported by grants from the National institute of Health to D.V.L. (DA06735) and C.V.X. (DA08571). We thank Nevin A. Lambert and David D. Mott for helpful suggestions.

Correspondence should be addressed to Dr. Cui-Wei Xie, Department of Psychiatry and Biobehavioral Sciences, University of California at Los Angeles School of Medicine, 760 Westwood Plaza, Los Angeles, CA 90024.

Copyright (O) 1995 Society for Neuroscience $0270-6474 / 95 / 153788-08 \$ 05.00 / 0$
}

CNS (Korn et al., 1992), hippocampal CAl neurons (Morishita and Sastry, 1991; Xie and Sastry, 1991) and cerebellar Purkinje cells (Kano et al., 1992) following tetanic stimulation of excitatory inputs to the same cells. It is unclear yet whether the LTP of inhibitory circuits is a common phenomenon inducible in other brain areas as well, and very little is known concerning the factors that modulate LTP induction in the inhibitory circuitry.

In the present study, we describe evidence that endogenous opioids may regulate the LTP of IPSCs of dentate granule cells following high-frequency stimulation of the LPP. The LPP originates in the entorhinal cortex and projects to the outer molccular layer of the dentate gyrus, providing both glutamatergic (White et al., 1977) and opioid (Gall et al., 1981) inputs to distal dendrites of granule cells. These LPP terminals also synapse on the interneuron dendrites in the molecular layer (Zipp et al., 1989). Immunocytochemical studies have demonstrated abundant GABAergic interneurons distributed throughout the dentate gyrus (Seress and Ribak, 1983; Babb et al., 1988; Han el al., 1993). The GABAergic axons from these interneurons synapse on granule cell dendrites, somata, and axon initial segments, constituting the anatomic substrate for the inhibitory synaptic signals recorded in granule cells during LPP stimulation. While high-frequency stimulation of the LPP has been reported to induce LTP of excitatory transmission at the LPP-granule cell synapses (Bramham et al., 1988; Xie and Lewis, 1991; Hanse and Gustafsson, 1992; Colino and Malenka, 1993), it remains to be examined whether LPP tetanization could induce similar potentiation of GABAergic input to the granule cell.

Furthermore, opioid peptides contained in the LPP projection, mainly enkephalins (Gall et al., 1981), have been found to facilitate LTP of excitatory transmission through $\mu$ (Xie and Lewis, 1990) and $\delta$ (Bramham et al., 1991a) receptors. Since activation of $\mu$ and $\delta$ receptors reduces GABA-mediated IPSCs while showing no direct enhancing effects on excitatory postsynaptic currents (EPSCs) in granule cells (Xie et al., 1992; Piguet and North, 1994), we have previously proposed (Xie and Lewis, 1991) that endogenous enkephalins may facilitate LTP of excitation at LPP synapses by suppressing GABAergic inputs to the granule cell (i.e., disinhibition). Here we further explore if endogenous opioids, through their disinhibitory actions, could also regulate the plasticity of inhibitory circuits in the dentate gyrus.

\section{Materials and Methods}

Preparation of hippocampal slices. Young (21-35 d old) male SpragueDawley rats were anesthetized with halothane and decapitated. Transverse hippocampal slices $500 \mu \mathrm{m}$ thick were prepared with a vibroslicer (Campden 752). They were then placed into a holding chamber in $32^{\circ} \mathrm{C}$ artificial cerebrospinal fluid (ACSF) bubbled continuously with $95 \% \mathrm{O}_{2} /$ $5 \% \mathrm{CO}_{2}$. The ACSF consisted of (mM) NaCl, 120; $\mathrm{NaHCO}_{3}, 25 ; \mathrm{KCl}$, 
3.3; $\mathrm{NaH}_{2} \mathrm{PO}_{4}, 1.23 ; \mathrm{CaCl}_{2}, 1.8 ; \mathrm{MgSO}_{4}, 1.2 ;$ and $\mathrm{D}$-glucose, 10 at $\mathrm{pH}$ 7.4. After at least $1 \mathrm{hr}$ of incubation in the holding chamber, the slices were transferred into a submerged $2 \mathrm{ml}$ recording chamber, where they were perfused at a rate of $3-4 \mathrm{ml} / \mathrm{min}$ with warmed ACSF $\left(32-34^{\circ} \mathrm{C}\right)$.

Synaptic stimulation and extracellular recording. A sharpened monopolar tungsten electrode was placed in the outer one-third of the dentate molecular layer to stimulate the LPP terminals as previously described (Xie and Lewis, 1991). A second stimulating electrode could be positioned in stratum lucidum of area $\mathrm{CA} 3 \mathrm{~b} / \mathrm{c}$ at least $100 \mu \mathrm{m}$ away from the dentate hilus to stimulate mossy fibers, or in the middle molecular layer to activate the medial perforant path (MPP). Constant-current rectangular stimulus pulses $(0.1 \mathrm{msec}, 30-500 \mu \mathrm{A})$ were delivered through the electrodes by an isolated stimulator. Extracellular responses were routinely monitored through recording electrodes placed in the granule cell layer. In some experiments test pulses subthreshold for granule cell population spikes were employed, in which case more than one site in the granule cell layer near the whole-cell recording electrode was tested, to ensure that the stimuli were subthreshold for all granule cells in the area.

Whole-cell voltage-clamp recording. Evoked synaptic currents were recorded from dentate granule cells using electrodes (3-5 M $\Omega$ ) pulled from World Precision Instruments glass on a Sutter puller. Electrodes were filled with a solution containing (mM) $N$-methyl-D-glucamine, 90; methanesulfonate, 90; CsF, 40; HEPES, 10; $\mathrm{MgCl}_{2}, 2 ; \mathrm{QX} 314,3$; and $\mathrm{Mg}-\mathrm{ATP}, 2$ at $\mathrm{pH}$ 7.2. In some cases $\mathrm{CsF}$ was replaced with $\mathrm{CsCl}$. After establishing the whole-cell configuration as previously described (Xie et al., 1992), the membrane potential usually fell to values close to 0 $\mathrm{mV}$ within $1-2 \mathrm{~min}$. The cell was then held at $0 \mathrm{mV}$ and whole-cell currents were recorded under voltage-clamp conditions using a patchclamp amplifier (Axopatch-1D). The holding potential could be transiently altered by voltage steps, which began $200 \mathrm{msec}$ before the synaptic stimulus and continued up to $1 \mathrm{sec}$. The cell input resistance was monitored by checking the deflection of holding current during the voltage steps. It was in a range of $150-600 \mathrm{M} \Omega$ in the cells examined. Measured series resistance was usually 10-20 M $\Omega$ and could be compensated up to $80 \%$. Recorded currents were filtered at $2 \mathrm{kHz}$, displayed on a digital oscilloscope (Nicolet 310 ), and stored on video tapes using a PCM data recorder (Vetter 200T).

Fluoride and the quaternary lidocaine derivative QX314 contained in the recording electrode suppressed voltage-dependent calcium (Kay et al., 1986) and sodium (Connors and Prince, 1982) currents, respectively. This treatment allowed us to hold granule cells at depolarized potentials without complications due to voltage-dependent currents. In addition, cesium (Johnston et al., 1980) and QX314 (Nathan et al., 1990) blocked potassium conductances, including $\mathrm{GABA}_{\mathrm{B}}$ receptor-mediated late

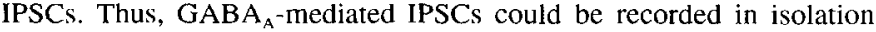
by stepping cells transiently $(1 \mathrm{sec})$ to the reversal potential for EPSCs during synaptic stimulation. The reversal potential for EPSCs determined in the presence of $\mathrm{GABA}_{\mathrm{A}}$ antagonist bicuculline methiodide (20 $\mu \mathrm{M})$ was $30 \pm 3 \mathrm{mV}(N=7)$ under our experiment conditions.

Experimental protocol. After formation of whole-cell patch, the cell was allowed to stabilize for $20 \mathrm{~min}$. The baseline responses evoked by single test pulses to the LPP or mossy fibers were observed during this period of time. The test pulse was delivered once every minute at a holding potential of $+30 \mathrm{mV}$ to isolate IPSCs as mentioned above. The stimulus intensity of test pulses was adjusted to evoke baseline IPSCs of 200-500 pA. When stable responses were obtained, a single highfrequency stimulus train $(100 \mathrm{~Hz}, 1 \mathrm{sec})$ was delivered to the LPP at a holding potential of $0 \mathrm{mV}$. The train stimuli used the same stimulus intensity as test pulses, or had a intensity of $100 \mu \mathrm{A}$ when the test pulse was below $100 \mu \mathrm{A}$. Posttrain responses to test pulses were monitored for at least $30 \mathrm{~min}$.

In the experiments where opioid antagonists were applied, drugs were usually added into the perfusion medium starting $10 \mathrm{~min}$ before LPP tetanus and continuously applied through the duration of the experiment. When using $\beta$-funaltrexamine $(\beta$-FNA) to irreversibly block $\mu$ receptors, slices were incubated with $\beta$-FNA $(10 \mu \mathrm{M})$ for $20 \mathrm{~min}$ and then washed with drug-frec ACSF for 1 hr to remove unbound $\beta$-FNA before start of experiments.

Data analysis. Data were analyzed off line. The amplitude of IPSC was measured at its peak. Reversal potentials of synaptic currents were determined by the intercept of the plot of currents versus holding voltages ( $I-V$ curve). Data are expressed as means $\pm S E$ and subjected to a one-way analysis of variance and Student's $t$ tests. Statistical significance was defined as $P<0.05$.

\section{Results}

Data were obtained from 102 stable (40 $\mathrm{min}$ to $3 \mathrm{hr}$ duration) whole-cell recordings from dentate granule cells with each granule cell recorded in a separate slice.

\section{Naloxone-revealed LTP of IPSCS}

Single test stimuli to the LPP terminals in the outer molecular layer evoked an outward current in granule cells held at +30 $\mathrm{mV}$ (Fig. $1 A$ ). The GABA $\mathrm{A}_{\mathrm{A}}$ antagonist bicuculline methiodide $(20 \mu \mathrm{M})$ completely blocked this outward current, indicating that it was a pure $\mathrm{GABA}_{\mathrm{A}}$ receptor-mediated current (Fig. 2). This current will be referred to simply as IPSC. Figure 1 illustrates the effect of LPP tetanization on IPSC amplitudes in the presence of the opioid antagonist naloxone. Application of $1 \mu \mathrm{M}$ naloxone for $10 \mathrm{~min}$ before the train did not cause significant change in IPSC amplitudes. However, the following stimulus train delivered in naloxone induced long-lasting increases in IPSC amplitudes. The time course of IPSC increase appeared slower than what one saw in studies of LTP of excitatory synaptic signals (Colino and Malenka, 1993). The potentiation of IPSCs started within $1 \mathrm{~min}$, gradually reached the peak 1025 min after the train, and typically lasted for the duration of the stable recording conditions (20 min to $2 \mathrm{hr}$ ).

In control experiments, the LPP was tetanized in ACSF without naloxone. The IPSC amplitude showed small increases (8$15 \%$ ) within $10 \mathrm{~min}$ after the train, but returned to the pretrain level thereafter (Fig. $1 B$ ). To exclude nonspecific effects of naloxonc, the MPP, a non-opioid containing pathway converging to granule cells, was tetanized in the presence of naloxone $(1 \mu \mathrm{M})$. The amplitude of MPP-evoked IPSCs measured 20 min after the train was $89 \pm 4 \%(N=8)$ of the pretrain value, indicating no induction of LTP.

To exclude any unknown artificial effects of intracellular fluoride on IPSCs due to its influence on calcium currents (Kay et al., 1986), $\mathrm{CsCl}$ was included in the electrode solution to replace $\mathrm{CsF}$ in another group of experiments. LPP tetanus in the presence of naloxone still induced LTP of IPSCs under such conditions. The average increase of IPSC amplitudes recorded with CsCl-containing electrodes was $55 \pm 22 \%(N=3) 25$ min after the train, which was not significantly different from that observed with $\mathrm{CsF}$-containing electrodes $(67 \pm 22 \%, N=7)$.

\section{Involvement of the feedforward, but not feedback, inhibitory circuitry}

Stimulation of the perforant path activates both feedforward and fecdback inhibitory circuitry (Anderson et al., 1966; Buzsáki and Eidelberg, 1981; Seress and Ribak, 1984; Scharfman, 1991). Feedforward inhibition is activated by excitatory perforant path synapses on interneurons. Feedback inhibition is activated if the perforant path stimulus causes granule cell discharge, thus activating recurrent mossy fiber collaterals that in turn excite inhibitory interneurons. Two groups of experiments were conducted to investigate which set of the inhibitory circuitry was involved in LTP of granule cell IPSCs.

First, we used very weak LPP test stimuli $(30-80 \mu \mathrm{A})$ to evoke IPSCs before and after LPP tetanus (Fig. $2 A, B$ ). These stimuli were subthreshold for evoking extracellular population spikes in the granule cell layer, thus causing no granule cell discharge. IPSCs evoked by these stimuli were considered to result from activation of the feedforward inhibitory circuitry. The amplitude of IPSCs increased by $50 \pm 14 \%(N=8)$ after 


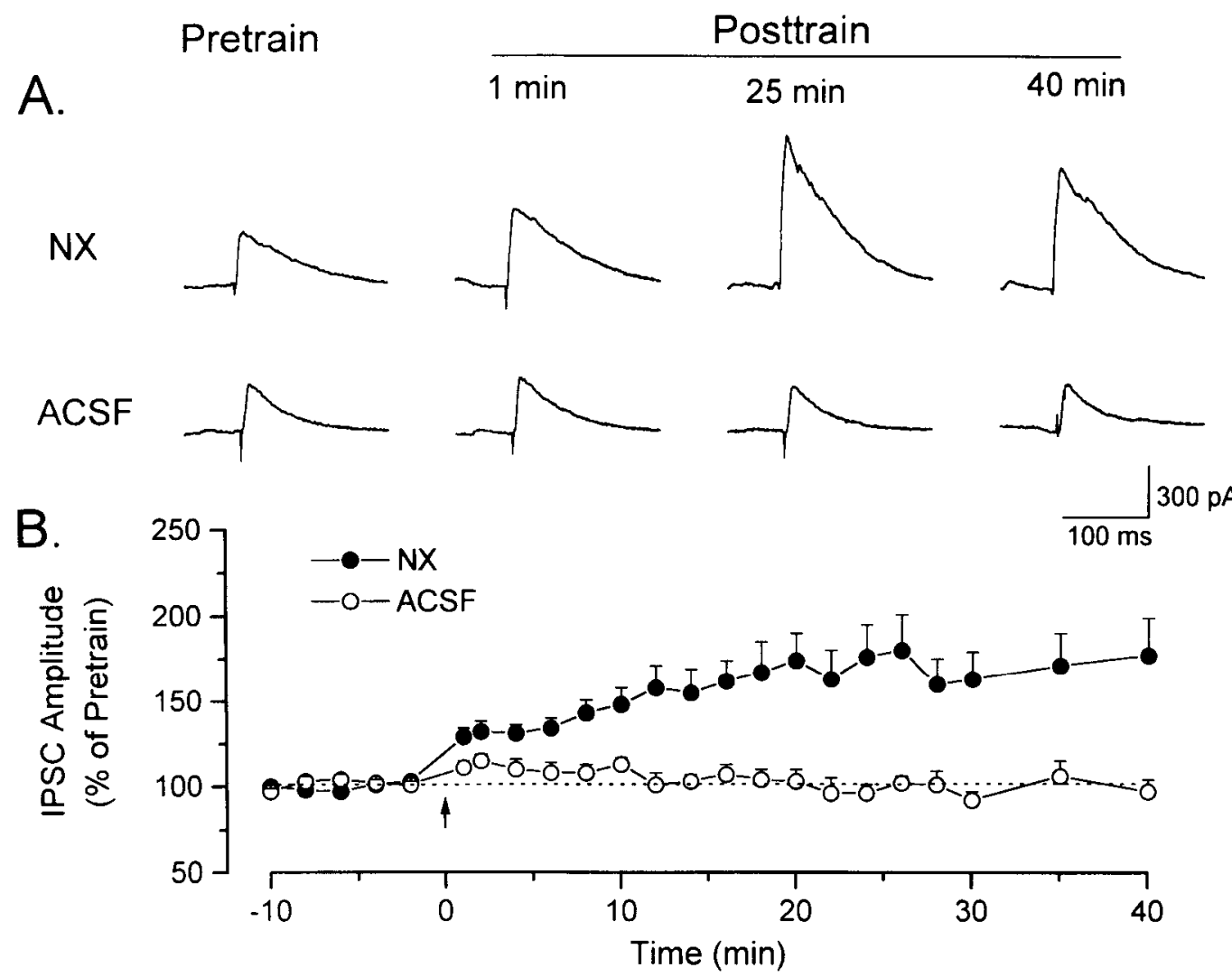

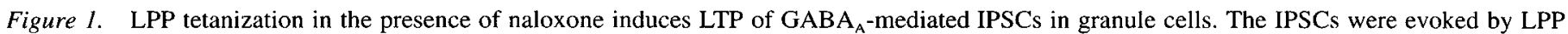
test pulses at a holding potential of $+30 \mathrm{mV}$. A, Representative experiments showing that LPP tetanus in $1 \mu \mathrm{M}$ naloxone $(N X)$, but not in ACSF, increases IPSC amplitudes. The stimulus artifacts here and in following figures were truncated. $B$, Group data showing the time course of IPSC potentiation. The high-frequency train $(100 \mathrm{~Hz}, 1 \mathrm{sec})$ was delivered to the LPP at $0 \mathrm{~min}$, as indicated by the arrow. Data were expressed as mean \pm SE. $N X, N=21 ; A C S F, N=15$. The two groups were significantly different $(P<0.05$ to $P<0.001)$ at all time points after train.

LPP tetanus in these experiments, indicating potentiation of the feedforward inhibitory circuitry.

Second, we attempted to measure LTP of the feedback inhibitory circuitry by monitoring mossy fiber-evoked IPSCs in granule cells during LPP tetanus. As previously reported (Mott et al., 1993), mossy fiber stimulation under our experimental conditions polysynaptically evoked pure GABAergic currents that could be completely abolished by GABA antagonists or by blockade of excitatory transmission. Since $\mathrm{GABA}_{\mathrm{B}}$-mediated late IPSCs had been blocked by intracellular cesium and QX314 in the present study, mossy fiber--evoked IPSCs here were entirely $\mathrm{GABA}_{\mathrm{A}}$-mediated currents that were sensitive to bicucullinc methiodide (Fig. 2C). In nine cells, both LPP- and mossy fiber-evoked IPSCs were monitored before and after the LPP train in the presence of naloxone (Fig. $2 C, D$ ). The LPP-evoked IPSCs were increased by $40 \pm 8 \% 20 \mathrm{~min}$ after the train $(P<$ 0.05 ), while the mossy fiber-evoked IPSCs were only increased by $4 \pm 4 \%$ at the same time, not significantly different from the pretrain amplitude. Thus, the feedback inhibitory circuitry appeared not potentiated during the induction of LTP.

\section{NMDA receptor dependence}

NMDA receptors are critically involved in LTP induction at most excitatory synapses. Although controversy exists (Bramham et al., 1991b), a number of studies have demonstrated that NMDA receptor antagonists block the induction of LTP at the LPP-granule cell synapses (Xie and Lewis, 1991; Hanse and Gustafsson, 1992; Zhang and Levy, 1992; Colino and Malenka,
1993). To determine if this is also the case for LTP of IPSCs observed here, the NMDA antagonist D-APV $(40 \mu \mathrm{M})$ was simultaneously applied with naloxone $(1 \mu \mathrm{M})$ before and during LPP tetanus (Fig. 3). Posttrain changes of IPSC amplitudes were less than $10 \%$ of the pretrain values within $30 \min (N=6)$, indicating a complete blockade of IPSC potentiation in these experiments. Thus, similar to LTP of excitatory synaptic signals, LTP of IPSCs also depended on activation of NMDA receptors.

\section{Effect of the $\beta$-adrenergic receptor antagonist}

Perforant path stimulation in the presence of naloxone was previously reported to cause a short-term increase in the amplitude of nuossy fiber-evoked IPSCs of CA3 pyramidal cells. The increase of IPSCs could be blocked by the $\beta$ adrenergic antagonist propranolol, indicating involvement of endogenous norepinephrine system (Caudle et al., 1991). To examine if such a mechanism was also involved in LTP of IPSCs observed in dentate, slices were simultaneously perfused with propranolol $(1 \mu \mathrm{M})$ and naloxone $(1 \mu \mathrm{M})$ for $10 \mathrm{~min}$ before LPP tetanus. No significant change in the baseline IPSCs was found in the presence of propranolol and naloxone. The following LPP train induced a 54 $\pm 18 \%$ increase in IPSC amplitudes 20 min after the train $(N$ $=4, P<0.05)$. Thus, the $\beta$-adrenergic antagonist did not block naloxone-revealed LTP of IPSC in the dentate. A representative experiment is shown in Figure 3. 
Pretrain Posttrain Superimp. BMI

A

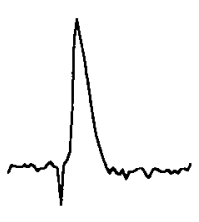

B
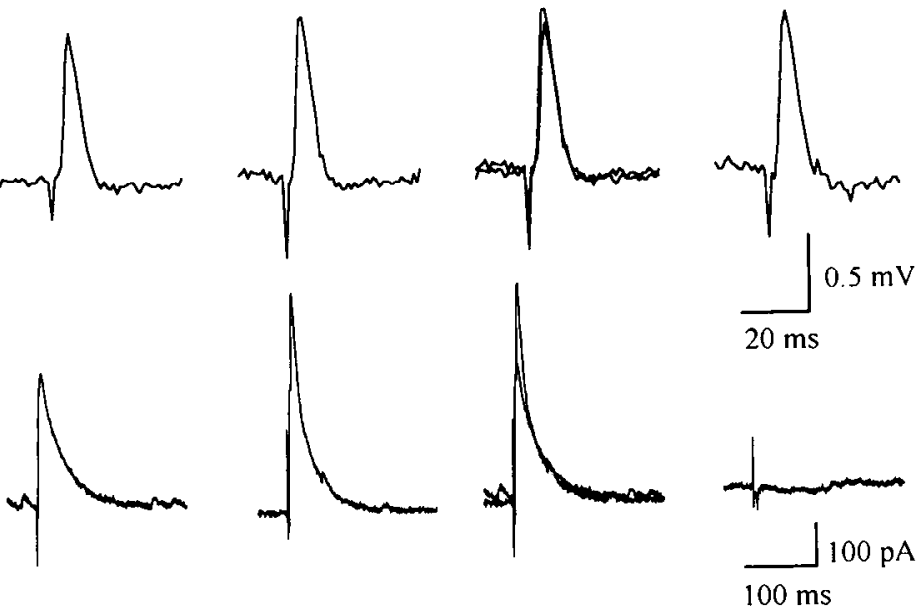

C
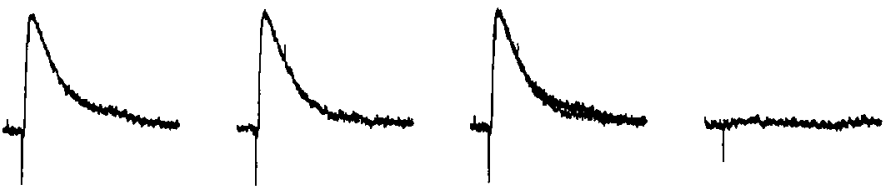

D
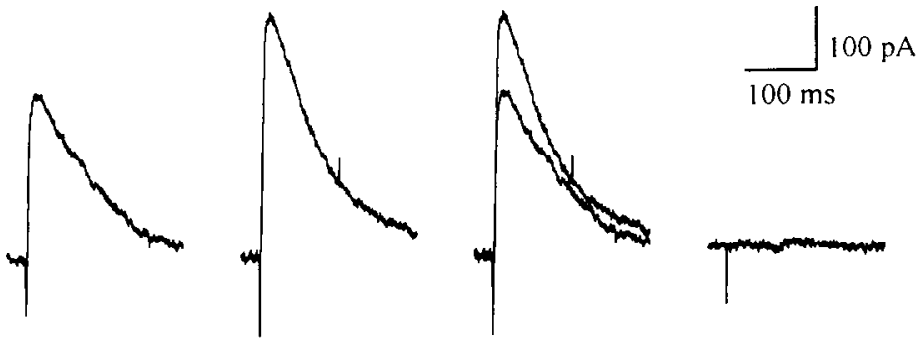

Pretrain

Posttrain

$1 \mathrm{~min}$

$25 \mathrm{~min}$

$40 \mathrm{~min}$

$\mathrm{D}-\mathrm{APV}$

$+\mathrm{NX}$
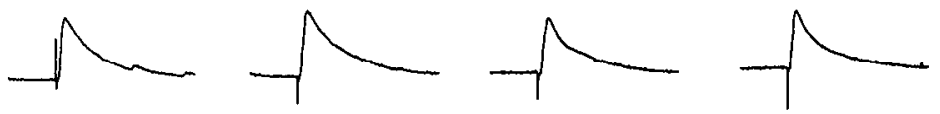

Propranolol

$+\mathrm{NX}$
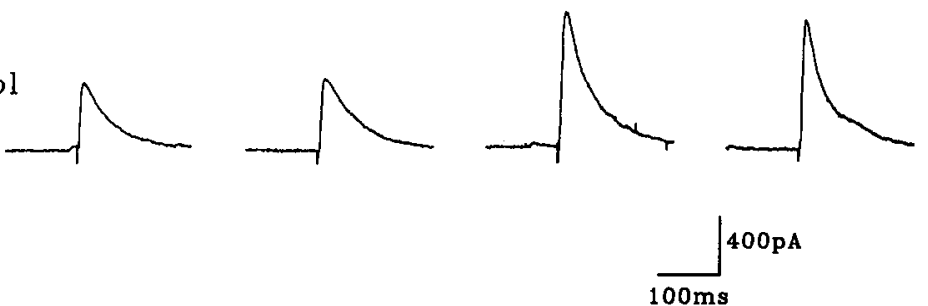

Figure 2. The feedforward, but not feedback, inhibitory circuitry is involved in NX-revealed LTP of IPSCs. $A$ and $B$, LPP test pulses with a low stimulus intensity $(60 \mu \mathrm{A})$ were applied before and after an LPP train. Extracellular responses $(A)$ and whole-cell currents $(B)$ were recorded from the same slice. Note the absence of granule cell population spikes and yet the potentiation of LPP-evoked IPSCs. $C$ and $D$, In another granule cell, IPSCs evoked by mossy fiber $(C)$ or LPP $(D)$ stimulation were simultaneously examined following the LPP train. Mossy fiber-evoked IPSCs were not potentiated after the train, despite a $48 \%$ increase in the amplitude of LPP-evoked IPSCs in the same cell. All trains were delivered in $1 \mu \mathrm{M}$ naloxone, and posttrain responses were obtained 20-25 min after the train. The $\mathrm{GABA}_{\mathrm{A}}$ antagonist bicuculline methiodide ( $B M I, 20$ $\mu M)$ was applied at end of experiments. Note the complete blockade of IPSCs by BMI.
Figure 3. Induction of NX-revealed LTP of IPSCs was blocked by the NMDA antagonist D-APV $(40 \mu \mathrm{M})$, but not by the $\beta$ adrenergic antagonist propranolol $(1 \mu \mathrm{M})$. Drugs were applied to two granule cells in separate slices. 


\section{Pretrain Posttrain Superimp}<smiles>CC1CCCC1NO</smiles>
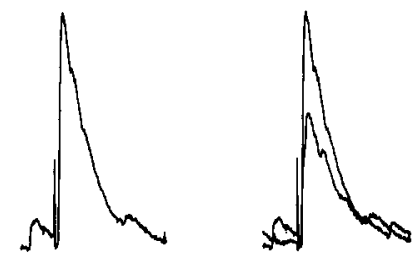

$-60 \mathrm{mV} \mathrm{N}_{m}$
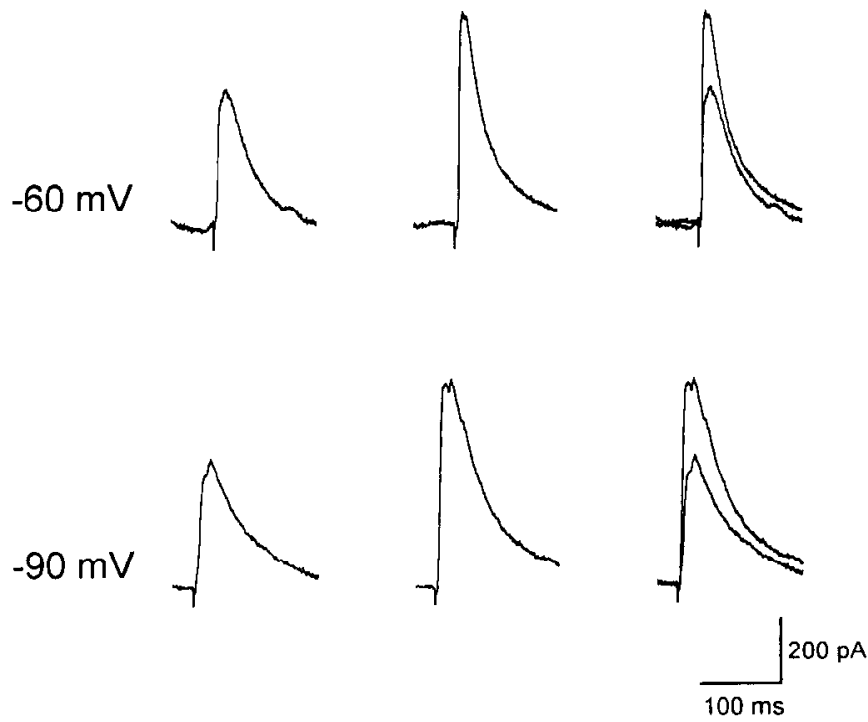

Figure 4. Hyperpolarization of the granule cell did not block induction of LTP of IPSCs. The LPP train was delivered in $1 \mu \mathrm{M}$ naloxone when holding granule cells at different membrane potentials $(0,-60,-90$ $\mathrm{mV}$ ). Posttrain responses were obtained $20 \mathrm{~min}$ after train at a holding potential of $+30 \mathrm{mv}$. Data were collected from three granule cells in separate slices.

\section{Effect of hyperpolarization of granule cell membrane.} potentials

As demonstrated above, LTP of IPSCs involved LPP-activated, feedforward inhibitory circuitry (Fig. 2). Thus, the increase in IPSC amplitudes could result from LTP occurring at either of two synapses, the LPP-interneuron synapse or the interneurongranule cell synapse. The latter possibility was further examined here.

Since induction of LTP of IPSCs is an NMDA receptor-dependent process (Fig. 3), manipulations that attenuate NMDAmediated currents in the postsynaptic neuron would be expected to impair this process. If LTP does occur at the interneurongranule cell synapse, hyperpolarization of the granule cell, which facilitates magnesium blockade of NMDA channels (Nowak et al,, 1984), should significantly suppress LTP induction, preventing the increase of IPSC amplitudes. To test this possibility, LPP trains were delivered when holding granule cell at different membrane potentials. It was found that changing the holding potential from $0 \mathrm{mV}$ to -60 or $-90 \mathrm{mV}$ did not affect the induction of LTP (Fig. 4). In a total of 11 granule cells, LPP trains delivered at a holding potential of $-90 \mathrm{mV}$ induced a 34 $\pm 18 \%$ increase in IPSC amplitudes $25 \mathrm{~min}$ after the train. This value was not significantly different from that observed in granule cells held at $0 \mathrm{mV}$ during the train $(49 \pm 15 \%, N=6)$. Thus, hyperpolarizing granule cell did not block LTP induction, suggesting that the potentiation might not occur at the interneuron-granule cell synapse.

\section{Selective opioid antagonist experiments}

To determine the subtype of opioid receptors involved in naloxone-revealed LTP of IPSCs, selective opioid antagonists were applied to different groups of slices to replace naloxone during LPP trains (Fig. 5). In the presence of naltrindole $(1 \mu \mathrm{M})$, a selective $\delta$ receptor antagonist, IPSC amplitudes showed longlasting increases following LPP tetanization. The time course of naltrindole-revealed LTP was similar to that induced in nalox-
Figure 5. Effects of selective opioid antagonists. The LPP train, indicated by the arrow, was applied to four groups of slices treated with ACSF or different antagonists. $N T I$, naltrindole $\mathrm{HCl}(1 \mu \mathrm{M}, N=5)$, $\delta$ receptor antagonist; nor- $B N I$, nor-binaltorphimine $(100 \mathrm{~nm}, N=5)$, $\kappa$ receptor antagonist. Both drugs were bath-applied starting 10 min before the train. $\beta-F N A, \beta$-funaltrexamine $\mathrm{HCl}(10 \mu \mathrm{M}, N=6)$, irreversible $\mu$ receptor blocker. Slices were pretreated with $\beta$-FNA for $20 \mathrm{~min}$ and then washed for $1 \mathrm{hr}$ before start of experiments. Data were expressed as mean \pm SE. ${ }^{*}, P<0.05$ as compared with the ACSF group.

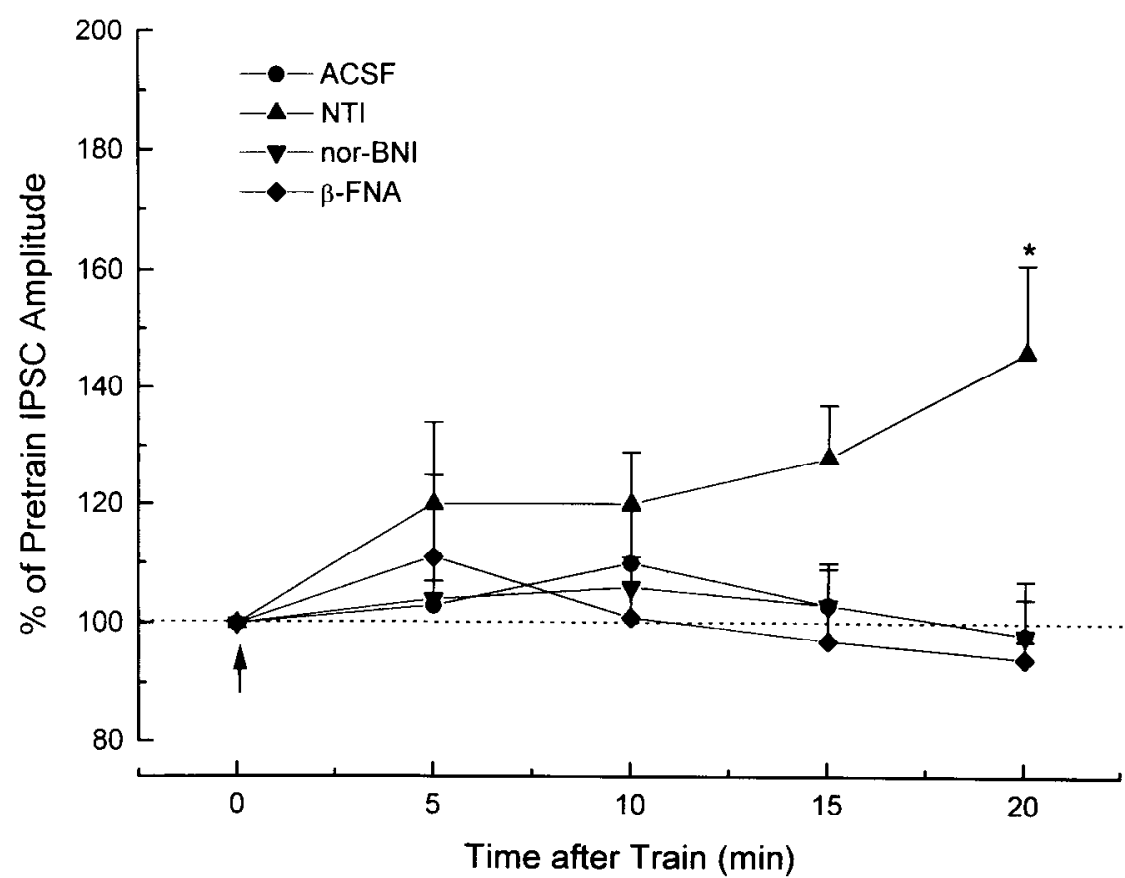


one. In another two groups of experiments, slices either were pretreated with $10 \mu \mathrm{M} \beta$-FNA, an irreversible $\mu$ antagonist, or were perfused with the $\kappa$ antagonist nor-binaltorphimine (norBNI; $100 \mathrm{nM}$ ) during LPP tetanus. LIP of IPSCs was observed in neither group of granule cells, indicating that blocking $\delta$, but not $\mu$ and $\kappa$, receptors was required to reveal LTP of IPSCs.

\section{Discussion}

The present study demonstrates that LPP-activated inhibitory circuits in the dentate are capable of undergoing LTP following LPP tetanization. However, the induction of this form of LTP appears to be inhibited by endogenous opioids. Blocking the effect of endogenous opioids on $\delta$ receptors is necessary for the full expression of LTP in these inhibitory circuits. Several earlier in vivo studies have attempted to examine plasticity of inhibition in the dentate in the absence of opioid antagonists, and the results have been mixed. A long-lasting reduction of paired-pulse inhibition following perforant path LTP was observed by Maru et al. (1989) in anesthetized rats. On the other hand, Buzsáki and Eidelberg (1982) observed increased probability of interneurons firing to single test stimuli following perforant path tetanization in extracellular unit recordings. Kairess et al. (1987) inferred increases in feedforward inhibition indirectly from changes in the EPSP slope versus population spike amplitude curve (E-S relationship) following perforant path tetanization in vivo. The latter two studies indicated a tetanus-induced, longlasting potentiation of synaptic inhibition in the absence of opioid antagonists, which we have not seen in this study. Differences in methodology and means of assessing inhibition might account for this discrepancy. Changes in synaptic inhibition were inferred indirectly in these two reports, whereas IPSCs of granule cells were measured directly in the present study. On the other hand, our experiments were conducted with in vitro slice preparation, where inhibitory circuits could be partially disrupted, possibly making LTP of inhibition more difficult to obtain. If activation of $\delta$ receptors normally suppresses LTP of inhibition, blockade of these receptors may be necessary to increase the robustness of the phenomenon for it to be seen in the slice preparation. This may explain why only a small and shortlasting potentiation of IPSCs was observed in control medium in this study.

In the present study, granule cell IPSCs were evoked polysynaptically by LPP stimulation that activated both feedforward and feedback inhibitory circuits in the dentate (Anderson et al., 1966; Buzsáki and Eidelberg, 1981; Seress and Ribak, 1984; Scharfman, 1991). Since mossy fiber-evoked IPSCs were not enhanced by LPP tetanization in the presence of naloxone, it was unlikely that the feedback circuitry was potentiated in our model. Furthermore, some of our experiments used test stimuli that were subthreshold for inducing granule cell discharge, thus only activating the feedforward inhibitory circuitry that has a lower threshold for synaptic activation (Buzsáki and Eidelberg, 1982; Scharfman, 1991). IPSC potentiation was still manifested in these experiments, indicating that LTP of IPSCs involves primarily the feedforward, but not feedback, inhibitory circuitry. LPP-activated feedforward inhibitory circuitry includes two synapses, the excitatory synapse driving GABAergic interneurons (LPP-interneuron synapses) and the GABAergic synapse on granule cells (interneuron-granule cell synapses). The potentiation of granule cell IPSCs could have resulted from LTP at either of these two synapses. Of these two sites, LTP at the GABAergic inhibitory synapse has been considered the less likely. One im- portant feature of LTP observed here is its NMDA receptor dependence, which differs from LTP of inhibitory synapses previously reported in mammalian brain. Two brief reports (Morishita and Sastry, 1991; Xie and Sastry, 1991) have described LTP of $\mathrm{GABA}_{\mathrm{A}}$ - and $\mathrm{GABA}_{\mathrm{B}}$-mediated IPSPs in CA1 pyramidal cells. This LTP is enhanced, rather than reduced, by chelation of intracellular calcium and blockade of protein kinase C, making it unlikely that it is NMDA receptor dependent. Another example is LTP of monosynaptic IPSPs of layer V cells in rat visual cortex, which can be induced in the presence of NMDA receptor antagonists (Komatsu, 1994).

The hyperpolarization experiments provide further evidence arguing against LTP of the interneuron-granule cell synapse. LTP of IPSCs was not prevented by hyperpolarizing granule cell membrane potentials to the level that has been shown to block NMDA receptor-dependent LTP in CA1 (Kato et al., 1993) and CA3 (Katsuki et al., 1991) pyramidal cells. Since the LTP is NMDA receptor dependent, this result indicates that the relevant NMDA receptors may not be on granule cells, and the LTP therefore does not occur at the interneuron-granule cell synapse. Although in our experiments the entire granule cell might not be hyperpolarized uniformly because of imperfect dendritic space clamp, the presence of intracellular cesium, which increases membrane resistance, and the short electrotonic length of the granule cells (Staley et al., 1992) should have facilitated the hyperpolarization to extend well into granule cell dendrites.

Overall, it appears more likely that the site of LTP is the LPPinterneuron synapses. A number of investigations have observed enhanced excilability of GABAergic interneurons following hippocampal formation LTP (Buzsáki and Eidelberg, 1982; Taube and Schwartzkroin, 1987; Stelzer et al., 1994). If LTP indeed occurs at the LPP-interneuron synapse, the polysynaptic nature of the potentiation may explain the time course difference between LTP of IPSCs observed here and LTP of EPSCs reported in other studies. By monitoring IPSCs at the granule cell, we were remotely measuring the effect of LTP of interneuron EPSCs. The time course of LTP of IPSC could therefore differ from that of interneuron EPSCs because of the influence of other factors, such as the postsynaptic excitability of interneurons that determines the threshold of interneuron firing, or any unknown transient changes in the inhibitory input to the interneurons. Finally, hippocampal interneurons are hyperpolarized by enkephalins (Madison and Nicoll, 1988), providing a possible mechanism whereby release of endogenous enkephalins from LPP terminals during tetanization might inhibit LTP at the LPP-interneuron synapse. It is conceivable that released enkephalins may act at $\delta$ receptors on interneurons to hyperpolarize their dendrites, which reduces calcium influx through NMDA channels and hence inhibits induction of LTP.

Different opioid receptor subtypes are known to play distinct roles in modulating LTP of excitatory synaptic signals in the hippocampus (Bramham et al., 1991a; Xie and Lewis, 1991; Wagner et al., 1993; Weisskopf et al., 1993; Terman et al., 1994). Our data suggest that this is also the case for opioid regulation of LTP in inhibitory circuits. Blockade of $\delta$, but not $\mu$ and $\kappa$, receptors was found responsible for naloxone-revealed LTP of IPSCs. It is particularly of interest that the $\mu$ antagonist $\beta$-FNA did not facilitate IPSC potentiation, though activation of $\mu$ receptors has been known to strongly inhibit IPSCs of granule cells (Xie et al., 1992; Piguet and North, 1994). This result implies that $\mu$ and $\delta$ opioids may have different effects on interneurons. Previous studies have suggested two distinct mecha- 
nisms for opioid-mediated disinhibition in the hippocampus, one mediated by hyperpolarization of interneurons (Zieglgänsberger et al., 1979; Madison and Nicoll, 1988) and the other by direct inhibition of GABA release from interneuronal terminals (Lambert et al., 1991; Cohen et al., 1992; Capogna et al., 1993). As discussed above, hyperpolarizing interneurons and consequently preventing LTP induction at the LPP-interneuron synapse could be a major effect of $\delta$ receptor activation. Differently, $\mu$ opioids may primarily act at interneuronal terminals to direct inhibit GABA release, as suggested by inhibition of monosynaptically evoked IPSCs and action potential-independent, spontaneous miniature IPSCs by $\mu$ agonists in the hippocampus (Xie et al., 1992; Capogna et al., 1993). Such a presynaptic mechanism may cause strong and short-lasting suppression of IPSCs, but not interfere with induction of LTP at LPP-interneuron synapses. Future studies using interneuron recordings will be needed to provide direct information regarding $\mu$ and $\delta$ opioid effects on these cells.

Regardless of the site of potentiation responsible for LTP of IPSCs reported here, our data reveal a novel aspect of opioid modulation of synaptic plasticity, the regulation of LTP in inhibitory circuits. Previous studies demonstrated that endogenous opioids acting at $\mu$ and $\delta$ receptors facilitated LTP of excitatory LPP input to granule cells (Xie and Lewis, 1990; Bramham et al., 1991a). Now we have evidence that, simultaneously, opioids suppress LTP of inhibitory inputs to the granule cell through $\delta$ receptors. The combination of these two aspects of opioid actions could strongly influence excitability of the LPP circuit. Since high-frequency stimuli are required for releasing endogenous opioids from hippocampal formation (Caudle et al., 1991), sustained high-frequency firing in the entorhinal cortex that releases opioids from the LPP would enhance LTP of EPSCs and suppress LTP of IPSCs in the LPP to granule cell circuit. Conversely, firing patterns that does not effectively release opioids, for example, brief episodes of low-frequency theta pattern firing may tend to favor LTP of IPSCs over LTP of EPSCs. Thus, opioid release may be envisioned as determining the direction of synaptic plasticity in this circuit toward inhibition versus excitation.

Morphological studies have demonstrated innervation of granule cell dendrites by GABAergic axons in conjunction with the perforant path terminals (Halasy and Somogyi, 1993; Han et al., 1993). The pairing of excitatory and inhibitory inputs on the same dendritic segments of granule cells may provide a mechanism for powerful and selective GABAergic control over the gain of excitatory inputs from the perforant path. Indeed, activation of $\mathrm{GABA}_{\mathrm{A}}$ receptors causes shunting inhibition of NMDA currents in granule cells (Staley and Mody, 1992), while reduction of $\mathrm{GABA}_{\mathrm{A}}$ inhibition facilitates induction of LTP of perforant path-evoked field EPSPs (Wigström and Gustafsson, 1983; Mott and Lewis, 1991). By preventing LTP in LPP-activated inhibitory circuits, endogenous opioids would be expected to attenuate tonic inhibitory control over granule cell dendrites, enhancing their responses to further excitatory input. This mechanism could play an important role in maintaining enhanced excitability of granule cell during repeated episodes of afferent activation, such as seizure activity.

\section{References}

Anderson P, Holmqvist B, Voorhoeve PE (1966) Entorhinal activation of dentate granule cells. Acta Physiol Scand 66:448-460.

Babb TL, Pretorius JK, Kupfer WR, Brown WJ (1988) Distribution of glutamate-decarboxylase immunoreactive neurons and synapses in the rat and monkey hippocampus: light and electron microscopy. $J$ Comp Neurol 278:121-138.

Bramham CR, Errington ML, Bliss TVP (1988) Naloxone blocks the induction of long-term potentiation in the lateral but not in the medial perforant pathway in the anesthetized rat. Brain Res 449:352-356.

Bramham CR, Milgram NW, Srcbro B (1991a) Delta opioid receptor activation is required to induce LTP of synaptic transmission in the lateral perforant path in vivo. Brain Res 567:42-50.

Bramham CR, Milgram NW, Srebro B (199lb) Activation of AP5 sensitive receptors is not required to induce LTP of synaptic transmission in the lateral perforant path. Eur J Neurosci 3:1300-1308.

Buzsáki G, Eidelberg E (1981) Commissural projection to the dentate gyrus of the rat: evidence for feedforward inhibition. Brain Res 230 : 346-350.

Buzsáki G, Eidelberg E (1982) Direct afferent excitation and long-term potentiation of hippocampal interneurons. J Neurophysiol 48:597607.

Capogna M, Gähwiler BH, Thompson SM (1993) Mechanism of muopioid receptor mediated presynaptic inhibition in the rat hippocampus in vitro. J Physiol (Lond) 470:539-558.

Caudle RM, Wagner JJ, Chavkin C (1991) Endogenous opioids released from perforant path modulate norepinephrine actions and inhibitory postsynaptic potentials in guinea pig CA3 pyramidal cells. $\mathrm{J}$ Pharmacol Exp Ther 258:18-26.

Cohen GA, Doze VA, Madison DV (1992) Opioid inhibition of GABA release from presynaptic terminals of rat hippocampal interneurons. Neuron 9:325-335.

Colino A, Malenka RC (1993) Mechanisms underlying induction of long-term potentiation in rat medial and lateral perforant paths in vitro. J Neurophysiol 69:1150-1159.

Connors BW, Prince DA (1982) Effects of local anesthetic QX314 on the membrane properties of hippocampal pyramidal neurons. J Pharmacol Exp Ther 220:476-481

Gall C, Brecha N, Karten HJ, Chang KJ (1981) Localization of enkephalin-like immunoreactivity to identified axonal and neuronal populations of the rat hippocampus. J Comp Neurol 198:335-350.

Halasy K, Somogyi P (1993) Subdivisions in the multiple GABAergic innervation of granule cells in the dentate gyrus of the rat hippocampus. Eur J Neurosci 5:411-429.

Han Z-S, Buhl EH, Lörinczi Z, Somogyi P (1993) A high degree of spatial selectivity in the axonal and dendritic domains of physiologically identified local-circuit neurons in the dentate gyrus of the rat hippocampus. Eur J Neurosci 5:395-410.

Hanse E, Gustafsson B (1992) Long-term potentiation and field EPSPs in the lateral and medial perforant paths in the dentate gyrus in vitro: a comparison. Eur J Neurosci 4:1191-1201.

Johnston D, Hablitz JJ, Wilson WA (1980) Voltage clamp discloses slow inward current in hippocampal burst-firing neurones. Nature 286:391-393

Kairess EW, Abraham WC, Bilkey DK, Goddard GV (1987) Field potential evidence for long-term potentiation of feed-forward inhibition in the rat dentate gyrus. Brain Res 401:87-94.

Kano M, Rexhausen U, Dreessen J, Konnerth A (1992) Synaptic excitation produces a long lasting rebound potentiation of inhibitory synaptic signals in cerebellar Purkinje cells. Nature 356:601-605.

Kato K, Clifford DB, Zorumski CF (1993) Long-term potentiation during whole-cell recording in rat hippocampal slices. Neurosci 53:3947.

Katsuki H, Kaneko S, Tajima A, Satoh M (1991) Separate mechanisms of long-term potentiation in two input systems to CA3 pyramidal neurons of rat hippocampal slices as revealed by whole-cell patchclamp technique. Neurosci Res 12:393-402.

Kay AR, Miles R, Wong RKS (1986) Intracellular fluoride alters the kinetic properties of calcium currents facilitating the investigation of synaptic events in hippocampal neurons. J Neurosci 6:2915-2920.

Komatsu Y (1994) Age-dependent long-term potentiation of inhibitory synaptic transmission in rat visual cortex. J Neurosci 14:6488-6499.

Korn H, Oda Y, Faber DS (1992) Long-term potentiation of inhibitory circuits and synapses in the central nervous system. Proc Natl Acad Sci USA 89:440-443.

Lambert NA, Harrison NL, Teyler TJ (1991) Evidence for mu opiate receptors on inhibitory terminals in area CAI of rat hippocampus. Neurosci Lett 124:101-104. 
Madison DV, Nicoll RA (1988) Enkephalin hyperpolarizes interneurones in the rat hippocampus. J Physiol (Lond) 398:123-130.

Maru E, Ashida H, Tatsuno J (1989) Long-lasting reduction of dentate paired-pulse depression following LTP-inducing tetanic stimulations of perforant path. Brain Res 478:112-120.

Morishita W, Sastry BR (1991) Chelation of postsynaptic $\mathrm{Ca}^{2+}$ facilitates long-term potentiation of hippocampal IPSPs. Neuroreport 2:533-536.

Mott DD, Lewis DV (1991) Facilitation of the induction of long-term potentiation by $\mathrm{GABA}_{\mathrm{B}}$ receptors. Science 252:1718-1720.

Mott DD, Xie CW, Wilson WA, Swartzwelder HS, Lewis DV (1993) $\mathrm{GABA}_{\mathrm{B}}$ autoreceptors mediate Activity-dependent disinhibition and enhanced signal transmission in the dentate gyrus. J Neurophysiol 69:674-691.

Nathan T, Jensen MS, Lambert JDC (1990) The slow inhibitory postsynaptic potential in rat hippocampal CA1 neurones is blocked by intracellular injection of QX-314. Neurosci Lett 110:309-313.

Nowak L. Bregestovski P, Ascher P, Herbet A, Prochiantz A (1984) Magnesium gates glutamate activated channels in mouse central neurones. Nature 307:462-465.

Piguet P, North RA (1994) Opioid actions at mu and delta receptors in the rat dentate gyrus in vitro. J Pharmacol Exp Ther 266:1139-1146.

Scharfman HE (1991) Dentate Hilar cells with dendrites in the molecular layer have lower thresholds for synaptic activation by perforant path than granule cells. J Neurosci 11:1660-1673.

Seress L, Ribak CE (1983) GABAergic cells in the dentate gyrus appear to be local circuit and projection neurons. Exp Brain Res 50: 173-182.

Seress L, Ribak CE (1984) Direct commissural connections to the basket cells of the hippocampal dentate gyrus: anatomical evidence for feedforward inhibition. J Neurocytol 13:215-225.

Staley KJ, Mody I (1992) Shunting of excitatory input to dentate gyrus granule cells by a depolarizing $\mathrm{GABA}_{\mathrm{A}}$ receptor mediated postsynaptic conductance. J Neurophysiol 68:197-212.

Staley KJ, Otis TS, Mody I (1992) Membrane properties of dentate gyrus granule cells: comparison of sharp microelectrode and whole cell recordings. J Neurophysiol 67:1346-1358.

Taube JS, Schwartzkroin PA (1987) Intraccllular recording from hip- pocampal CA1 interneurons before and after development of longterm potentiation. Brain Res 419:32-38.

Terman GW, Wagner JJ, Chavkin C (1994) Kappa opioids inhibit induction of long-term potentiation in the dentate gyrus of the guinea pig hippocampus. J Neurosci 14:4740-4747.

Wagner JJ, Terman GW, Chavkin C (1993) Endogenous dynorphins inhibit excitatory neurotransmission and block LTP induction in the hippocampus. Nature 363:451-454.

Weisskopf MG, Zalutsky RA, Nicoll RA (1993) The opioid peptide dynorphin mediates heterosynaptic depression of hippocampal mossy fibre synapses and modulates long-term potentiation. Nature 362: 423-427.

White WF, Nadler JV, Hamberger A, Cotman CW (1977) Glutamate as transmitter of hippocampal perforant path. Nature 270:356-357.

Wigström H, Gustafsson B (1983) Facilitated induction of hippocampal long-lasting potentiation during blockade of inhibition. Nature 301: 603-604

Xie CW, Lewis DV (1990) Receptor mechanisms of opioid enhancement of long-term potentiation in the lateral perforant path. Soc Neurosci Abstr 16:981.

Xie CW, Lewis DV (1991) Opioid-mediated facilitation of long term potentiation at the lateral perforant path-dentate granule cell synapse. J Pharmacol Exp Ther 256:289-295.

Xic CW, Morrisctt RA, Lcwis DV (1992) Mu opioid receptor-mediated modulation of synaptic currents in dentate granule cells of rat hippocampus. J Neurophysiol 68:1113-1120.

Xie Z, Sastry BR (1991) Inhibition of protein kinase activity enhances long-term potentiation of hippocampal IPSPs. NeuroReport 2:389392.

Zhang DX, Levy WB (1992) Ketamine blocks the induction of LTP at the lateral entorhinal cortex-dentate gyrus synapses. Brain Res 593: 124-127.

Zieglgänsberger W, French ED, Siggins GR, Bloom FE (1979) Opioid peptides may excite hippocampal pyramidal neurons by inhibiting adjacent inhibitory interneurons. Science 205:415-417.

Zipp F, Nitsch R, Soriano E, Frotscher M (1989) Entorhinal fibers form synaptic contacts on parvalbumin-immunoreactive neurons in the rat fascia dentata. Brain Res 495:161-166. 